\title{
The Influence of GLOBE Culture Dimensions on Entrepreneurial Orientation in Tourism and Medical Service Sectors in Serbia
}

\author{
Milena Nedeljković Knežević ${ }^{*}$, Vanja PavlukovićA \\ Received: December 05, 2019 | Revised: March 30, 2020 | Accepted: April 04, 2020 \\ doi: $10.5937 / g p 24-24303$
}

\begin{abstract}
The main objective of the research is to examine, for the first time, the influence of dimensions of culture according to the GLOBE model on the dimensions of entrepreneurial orientation. The research sample belongs to the service sector within the transitional society of Serbia, i.e. tourism and medical sector, which are linked through the ever-growing health tourism industry. Different influences of dimensions of culture (uncertainty avoidance, performance orientation, group collectivism, assertiveness and gender equality) on dimensions of entrepreneurial orientation (work ethic. innovativeness, empathy, autonomy and risk readiness) are confirmed. The obtained results are important for defining the cultural framework which influences the development of entrepreneurial activities within tourism and health service sectors in Serbia.
\end{abstract}

Keywords: GLOBE model; culture dimensions; entrepreneurial orientation; service sector; transitional society

\section{Introduction}

Today's transitional societies are characterized (Munck, 2002) by a number of cultural specificities that cannot be found in highly developed capitalist societies which, particularly in the former socialist countries, are based on decades of strong focus on collectivism and a lack of orientation toward performance. There are, of course, significant cultural differences among the different transitional societies, having different histories and transition pathways (Mebrahtu et al., 2000). Numerous researchers of the economic problems of developing countries believe that the limited nature of economic development of these societies is a result of certain cultural patterns that have, to some extent, blocked them in the use of rational economic behavior and market functioning. Rostow (1960) believed that it was precisely detraditionalization that can stir the journey of such societies toward modernity. Particularly relevant to this work is the cultural context of entrepreneurship development.

Freytag and Thurik (2007) consider that low national income and poor technological development are not the main contributing factors to the low level of entrepreneurial activity, but that the differences observed are mainly institutional and of cultural nature. Therefore, many studies attribute a high level of entrepreneurial activity to the influence of cultural values such as freedom, independence, need for achievement, individualism/collectivism and materialism (Morris et al., 1994; Spence, 1985).

Entrepreneurship in tourism has made exceptional contributions to the global economic development (Lordkipanidze et al., 2005). When it comes to devel-

\footnotetext{
A University of Novi Sad, Faculty of Science, Department of Geography, Tourism and Hotel Management, Trg Dositeja Obradovića 3, 21000 Novi Sad, Serbia; milena.nedeljkovic@dgt.uns.ac.rs; vanja.dragicevic@dgt.uns.ac.rs

* Corresponding author: Milena Nedeljković Knežević, e-mail: milena.nedeljkovic@dgt.uns.ac.rs
} 
oping countries, rapid increase in international tourist arrivals is partly influenced by the growing interest of postmodern tourists for destinations with cultural specificities and attractive cultural heritage. These destinations are challenging for postmodern tourists who are to some extent saturated with experiences in the well-known European destinations. Therefore, many countries have invested significant funds in the last decade to stimulate tourism development and especially entrepreneurship in tourism (Chang, 2011; Carmichael \& Morrison, 2011).

The main goal of this study is to examine the influence of cultural dimensions in Serbia on entrepreneurial orientation in two service sectors, healthcare and tourism.

Many countries have recognized the possibility of linking the entrepreneurship activities between tourism and healthcare. Medical tourism refers to the cross-border healthcare, motivated by lower costs, avoidance of long waiting times or services not available in one's own country. Increasing attention is being paid to attracting medical tourists, including activities aimed at providing entertainment during the pre- and post-operative periods (Hopkins et al., 2010).
According to the Zion Market Research (2018) report, global medical tourism market was valued at approximately USD 15.5 billion in 2017 and is expected to generate revenue of around USD 28.0 billion by the end of 2024. The industry has grown substantially in the past decades as citizens of the EU travel from richer countries like the United Kingdom, Sweden, Germany, Netherlands, and Ireland to seek affordable healthcare in other countries, primarily in Eastern Europe. Health tourism brings in $€ 46.9$ billion in revenue which represents $4.6 \%$ of overall tourism revenues and $0.33 \%$ of EU28 GDP (Fink, 2018).

The rapid development of medical tourism has led to the expansion of destinations which are specialized for dental tourism (Poland, Hungary, and Serbia), heart surgery (Turkey), hernias or other medical treatments (Connell, 2006). The influx of medical tourists brings numerous benefits to host destinations. It contributes to country's overall economy, creates jobs and opportunities for further development through the supply chains. As a growing tourism market segment, medical tourism provides numerous opportunities for entrepreneurial activities (Gredičak \& Demonja, 2019).

\section{Conceptual definition of culture and GLOBE model}

Although there is no complete consensus on the definition of the term culture, scholars mostly agree that culture can be viewed as a set of parameters that allow one collectivity to be differentiated from another. Within this study we focus on the cultural indicators (parameters) in relation to tourism and entrepreneurship. Namely, for the last thirty years, the research, mostly by Hofstede (2001) and the group gathered around the GLOBE (Global Leadership and Organizational Behavior Effectiveness) project, has attracted attention of the scholars in the field of management, organizational behavior and entrepreneurship (House et al., 2002).

For the purpose of this study, we used the GLOBE model, because it is widely accepted and has found numerous applications in various fields including entrepreneurship. Furthermore, the orientation of society or organization towards performance is of great importance for entrepreneurial activities, which was not investigated within the Hofstede's model.

GLOBE cultural dimensions are defined as follows:

1. Uncertainty Avoidance is the extent to which member of an organization or society strive to avoid uncertainty by reliance on social norms, rituals, and bureaucratic practices to alleviate the unpredictability of future events.
2. Power Distance is the degree to which members of an organization or society expect and agree that power should be unequally shared.

3. Collectivism I: Societal Collectivism reflects the degree to which organizational and societal institutional practices encourage and reward collective distribution of resources and collective action.

4. Collectivism II: In-Group Collectivism reflects the degree to which individuals express pride, loyalty, and cohesiveness in their organizations or families.

5. Gender Egalitarianism is the extent to which an organization or a society minimizes role differences and gender discrimination.

6. Assertiveness is the degree to which individuals in organizations or societies are assertive, confrontational, and aggressive in social relationships.

7. Future Orientation is the degree to which individuals in organizations or societies engage in futureoriented behaviors such as planning, investing in the future, and delaying gratification.

8. Performance Orientation refers to the extent to which an organization or society encourages and rewards group members for performance improvement and excellence.

9. Humane Orientation is the degree to which individuals in organizations or societies encourage and reward individuals for being fair, altruistic, friend- 
ly, generous, caring, and kind to others (House et al. 2002, pp.5-6).

The GLOBE model has two sub-models: the value aspect of the cultural dimensions (or the situation as it should be in the society or in the organization in the opinion of respondents belonging to the research society) and the perception of the real situation in the society or organization.

\section{Culture and entrepreneurship}

Hayton et al. (2002) believe that national culture can, on an individual level, encourage or demotivate entrepreneurial activities, inter alia, by creating a cultural framework to identify opportunities for entrepreneurial activities that are appreciated and supported by a number of incentive measures.

Research by Morris et al. (1994) suggests that in individualistic cultures, managers tend to be autonomous and independent and more willing than managers in collectivist cultures to adapt to high-risk situations. Entrepreneurs in an individualistic culture view external environments much more optimistically than entrepreneurs belonging to the society with a low degree of individualism (Palich \& Bagby, 1995). In societies characterized by a high level of power distance, there is a general tendency to maintain an established social system and accept its own position in it, without a strong motivation to change one's status (Hojat et al., 2002). Managers in cultures characterized by a low degree of power distance are more willing to take risky actions in order to improve the strategic position of the organization they manage (Shane, 1993).

Some authors point to a negative correlation between uncertainty avoidance and entrepreneurial activity, considering that a society with a high degree of uncertainty avoidance is not prone to risk-taking activities and that members of such society have low levels of readiness to changes, which are very important for entrepreneurial activities (Thomas \& Mueller, 2000). In societies with a high degree of human orientation, the support of the environment for entrepreneurial activities can be expected even in the event of initial failures, which can be particularly significant in societies with low levels of economic development. As entrepreneurs are aspiring to financial rewards as a consequence of high performance, a society characterized by the practice of rewarding high performance provides a good environment for the growth of entrepreneurial activities. Companies with a high future orientation provide a favorable framework for the development of entrepreneurial activities, which involves anticipating future opportunities for entrepreneurial activities through active analysis of future trends in the market. A study by Emrich et al. (2004) concludes that in societies characterized by high levels of gender equality, women have high social status and participation in the workforce and a similar educational level to men, and women's participation in entrepreneurial activities is also higher than in societies characterized by low levels of gender equality.

National cultures are particularly important for entrepreneurs in the tourism industry, to maximize the satisfaction of tourists from different countries with the service quality. Previous studies examined the impact of national cultures on the tourists' behavior (Money \& Crotts, 2003; Tsang \& Ap, 2007), as well as on local residents' attitudes towards tourism (Pavluković et al., 2017). Nedeljković, Koković and Nedeljković (2010) showcase the relationship between culture and tourists' behavior in the context of choosing tourism products. Service providers in the healthcare sector are also required to have a high degree of cultural sensitivity, which is of particular importance in a multicultural society (Bonder et al., 2001).

\section{Entrepreneurial orientation}

The widely used entrepreneurial orientation (EO) (Lumpkin \& Dess, 2001), introduced by Covin and Slevin (1986), focuses on the following dimensions of this construct: risk taking, innovativeness and proactiveness, and is the result of an adaptation of the work of Miller and Friesen (1982) and Khandwalla (1976/77). Unlike personality dimensions that are dispositional and stable over time, entrepreneurial orientations are culturally conditioned and under the influence of the environment (Özsomer et al., 1997; Thomas \& Mueller, 200o).

Thus, Baluku et al. (2019) evidence that personal cultural orientations and cultural intelligence impact the subjective success in self-employment, For the purposes of this research, a questionnaire was used to measure the following dimensions of entrepreneurial orientation: innovativeness, proactiveness, autonomy, work ethic, risk readiness and empathy. 
Innovativeness refers to having new ideas in relation to certain relevant groups, markets and environments, and can relate to products and services as well as to administration or technological processes (Lumpkin \& Dess, 1997; Avlonitis \& Salavou, 2007). There are numerous examples of innovativeness in the tourism sector (Bilgihan \& Nejad, 2015), which could be manifested in the selection of products that may be of interest to a particular niche. For example, over the last ten years, a number of new forms of tourism have developed, such as adventure tourism, experiential tourism.

Entrepreneur proactiveness is a behavioral syndrome that involves recognizing the opportunities that the market provides, boldness aimed at starting an entrepreneurial venture, during the realization of the venture, but also persistence in overcoming the difficulties that may be encountered in realizing the entrepreneurial venture (Lumpkin \& Dess, 1996). Cultures that emphasize entrepreneurial initiative by encouraging entrepreneurs to pursue and anticipate opportunities and to participate in new or emerging markets are classified as proactive (Lee \& Peterson, 2000).

Autonomy is also present in successful entrepreneurs and presents the ability to make independent decisions and realize their own ideas and visions. This is one of the factors that may be present when a firm engages in new entry (Covin \& Wales, 2012). Also, it may help develop new ventures or improve business practices (Albert \& Couture, 2013).

Risk orientation is an important component of a strong EO (Lee \& Peterson, 2000). Entrepreneurial activity also involves entering an unfamiliar terrain, which also enhances the possibility of making errors in the assessment, for example, that the market will accept a new product or service. Naldi et al. (2007) found that risk taking was a distinct dimension of entrepreneurial orientation in family firms and that it was positively associated with proactiveness and innovation. They also found that family firms took risk to a lesser extent than nonfamily firms.

An entrepreneur is often considered as self-centered personality thinking only of his or her well-being, but many well-known entrepreneurs have been driven by a desire to contribute to the well-being of the society (Montanye, 2006). When it comes to the service sector, especially health sector, an important dimension of entrepreneurial orientation is empathy, which is also one of the dimensions of emotional intelligence. It signifies a healthcare professional's ability to understand patient's emotions, which can contribute to the more caring treatment. Service is characterized by intangibility and therefore the perception of the quality of service by the consumer is also based on the emotional response produced by the service. Empathy is very important for successful entrepreneurial activities in tourism sector particularly due to prolonged nature of service encounter.

\section{Within this study we hypothesize:}

H1: GLOBE Culture dimensions are predictors of entrepreneurial orientation dimensions.

To the best of our knowledge this is the first study investigating the relationship between all nine GLOBE dimensions and six dimensions of EO, therefore offering significant insight on the impact of culture dimensions on entrepreneurial orientation.

\section{Methodology}

\section{Questionnaires}

The questionnaire was composed of three sections: i) survey of demographic profile of respondents, ii) entrepreneurial orientation and iii) dimensions of culture. Questionnaire to measure entrepreneurial orientation was reused from the literature study: Hermansen-Kobulnicky and Moss (2004) (Cronbach index greater than 0.9 for all dimensions). This questionnaire uses ratings from 1- strongly disagree to 7 - strongly agree, for assessing the following dimensions of entrepreneurial orientation: proactivity, work ethic, empathetic service provider, innovativeness, autonomy, risk readiness. The questionnaire for measuring social culture is reused from the work: House, Hanges, Javidan, Dorfman and Gupta (2004). Reliability for all dimensions is above 0.5 (House et al., 2004).

This questionnaire uses the ratings in the range 1strongly disagree to 7 - strongly agree, for assessing the following dimensions of social culture: uncertainty avoidance, future orientation, performance orientation, institutional collectivism, group collectivism, assertiveness, people orientation, power distance.

The questionnaires were distributed to students of tourism, medicine and pharmacy, in dozens of travel agencies, pharmacies and doctors' offices. A total of 250 questionnaires were distributed, of which 207 returned correctly completed questionnaires. All respondents were informed that participation in the survey was anonymous and the goal of the survey was explained. Respondents provided answers using the standard pen and paper method.

\section{Sample structure}

Out of 207 respondents, 108 of them were medical and tourism students while 99 were employed in the med- 
ical (including pharmacy) and tourism sectors. The sample contained 60 male respondents $(29 \%)$ and 147 female respondents (71\%). There were 135 students and employed persons with the high school degree $(62 \%)$, 9 of the respondents completed a 2-year college higher education (4.3\%), 44 completed a 4 -year University education (21.3\%) and 19 of them completed masters or
$\mathrm{PhD}$ education (9.2\%). Regarding the age of respondents, $69.1 \%$ belonged to the group between 19 and 35 years of age, $21.7 \%$ of respondents were in the group between 35 and 45 years year of age, $6.3 \%$ between 45 and 55 years of age and $2.9 \%$ of respondents above 55 years of age. Hence, over $80 \%$ of respondents were under 45 years of age.

\section{Results}

\section{Descriptive statistics}

Descriptive statistics for the dimensions of culture according to the GLOBE model are given in Table 1. Respondents rate the level of power distance very high (5.65), which means that despite the changes that Serbian society experienced after the socialist period, there was no significant reduction in power distance. The perception of performance orientation is very low (2.81), which indicates that society has not yet (in the development of entrepreneurship). The reliability of these questionnaires is lower than recommended, but it is acceptable for questionnaires with a small number of items.

The Table 2 shows that the average values of all dimensions of entrepreneurial orientation are very high, which could mean that at the individual level there are favorable conditions for the development of entrepreneurship.

Table 1. Descriptive statistics for the dimensions of culture according to the GLOBE model.

\begin{tabular}{|l|c|c|c|c|c|c|c|c|}
\hline & & Min. & Max. & Average & St. dev. & $\begin{array}{c}\text { Skewness } \\
\text { (St err. 0.169) }\end{array}$ & $\begin{array}{c}\text { Kurtosis } \\
\text { (St. err 0.337) }\end{array}$ & Reliability \\
\hline Uncertainty Avoidance & UA & 1.00 & 6.33 & 3.4960 & 1.20850 & -0.253 & -0.519 & 0.54 \\
\hline Future Orientation & FO & 1.00 & 6.60 & 2.9691 & 1.11713 & 0.077 & -0.400 & 0.61 \\
\hline Performance Orientation & PO & 1.00 & 6.50 & 2.8140 & 1.32487 & 0.433 & -0.457 & 0.48 \\
\hline institutional colectivism & IC & 1.00 & 6.67 & 3.1626 & 1.20939 & 0.090 & -0.310 & 0.57 \\
\hline In group collectivism & GC & 1.33 & 7.00 & 4.8841 & 1.30160 & -0.349 & -0.630 & 0.59 \\
\hline Assertivity & AS & 1.33 & 7.00 & 4.5411 & 1.08102 & -0.009 & -0.343 & 0.71 \\
\hline Human Orientation & HO & 1.00 & 5.50 & 3.1171 & 1.00929 & 0.117 & -0.409 & 0.65 \\
\hline Gender equality & GE & 1.00 & 7.00 & 5.6522 & 1.34734 & -1.057 & 0.957 & 0.67 \\
\hline Power distance & PD & 2.00 & 7.00 & 5.6510 & 1.08239 & -0.762 & 0.232 & 0.75 \\
\hline
\end{tabular}

Table 2. Descriptive statistics for dimensions of entrepreneurial orientation

\begin{tabular}{|l|l|l|l|l|l|l|}
\hline Dimension & Abbreviation & Min. & Max & Average & St.dev. & Cronbach alpha. \\
\hline Proactiveness & Proact & 1.00 & 7.00 & 5.4348 & 1.09290 & 0.632 \\
\hline Work Ethic & WE & 1.00 & 7.00 & 5.3671 & 1.32809 & 0.810 \\
\hline $\begin{array}{l}\text { Empathetic service } \\
\text { provider }\end{array}$ & Empat & 1.25 & 7.00 & 5.4481 & 1.08583 & 0.693 \\
\hline Innovativeness & Innovat & 1.00 & 7.00 & 5.0870 & 1.21342 & 0.704 \\
\hline Autonomy & Auton & 1.00 & 7.00 & 5.3816 & 1.26827 & 0.792 \\
\hline Risk Taking & RiskT & 1.00 & 7.00 & 5.3092 & 1.30964 & 0.662 \\
\hline
\end{tabular}

transformed in the direction of promoting high performance and rewarding them adequately. Also, the orientation towards the future is low (2.96), which also indicates a lack of strategic planning in our society. Unlike group collectivism, which is relatively high (4.88), institutional collectivism is perceived as very low (3.16), which can be the result of insufficient support from state institutions in many sectors

\section{Regression models}

Regression model with the dependent variable proactiveness and independent variable dimensions of GLOBE culture is significant at the $\mathrm{p}=0.00$ level and the multiple correlation coefficient $\mathrm{R}=0.260$. However, the model explains only about 7\% (R-square 0.067) of the variability in the dependent variable and no significant correlations were observed. 
Table 3. Regression models with the EO dimensions as dependent variables and independent variable dimensions of GLOBE culture

\begin{tabular}{|c|c|c|c|c|c|c|c|c|c|c|c|}
\hline & \multicolumn{10}{|c|}{ EO Dimension } \\
\hline & & \multicolumn{2}{|c|}{ WE } & \multicolumn{2}{|c|}{ Empat } & \multicolumn{2}{|c|}{ Innovat } & \multicolumn{2}{|c|}{ Auton } & \multicolumn{2}{|c|}{ RiskT } \\
\hline & & Beta & $P$ & Beta & $P$ & Beta & $P$ & Beta & $P$ & Beta & $P$ \\
\hline \multirow{10}{*}{1} & Constant & & 0.000 & & 0.000 & & 0.000 & & 0.000 & & 0.000 \\
\hline & UA & -0.173 & 0.018 & -0.056 & 0.437 & -0.064 & 0.421 & -0.126 & 0.074 & -0.190 & 0.006 \\
\hline & $\mathrm{FO}$ & -0.097 & 0.208 & -0.069 & 0.362 & 0.009 & 0.911 & -0.024 & 0.750 & -0.013 & 0.856 \\
\hline & PO & 0.155 & 0.047 & 0.064 & 0.399 & 0.024 & 0.777 & 0.080 & 0.287 & 0.116 & 0.113 \\
\hline & IC & 0.087 & 0.205 & -0.017 & 0.804 & -0.024 & 0.751 & 0.062 & 0.352 & 0.080 & 0.217 \\
\hline & GC & 0.224 & 0.002 & 0.344 & 0.000 & 0.183 & 0.020 & 0.332 & 0.000 & 0.301 & 0.000 \\
\hline & AS & -0.245 & 0.001 & -0.316 & 0.000 & -0.266 & 0.001 & -0.276 & 0.000 & -0.275 & 0.000 \\
\hline & $\mathrm{HO}$ & -0.032 & 0.647 & -0.144 & 0.069 & -0.108 & 0.159 & -0.124 & 0.073 & -0.141 & 0.056 \\
\hline & GE & -0.097 & 0.186 & -0.108 & 0.133 & -0.167 & 0.037 & -0.063 & 0.372 & -0.080 & 0.249 \\
\hline & PD & 0.018 & 0.819 & 0.048 & 0.529 & 0.125 & 0.136 & 0.078 & 0.296 & 0.115 & 0.115 \\
\hline
\end{tabular}

Regression model with the dependent variable work ethic and independent variable dimensions of GLOBE culture is significant at the $\mathrm{p}=0.00$ level (Table 3 ). The multiple correlation coefficient $\mathrm{R}=0.531$ and the model explains about $28 \%$ of the variability in the dependent variable. Beta coefficients of avoidance of uncertainty, performance orientation, group collectivism and assertiveness are statistically significant.

Regression model with the dependent variable empathy and independent variable dimensions of GLOBE culture is significant at the $\mathrm{p}=0.00$ level. The multiple correlation coefficient $\mathrm{R}=0.554$ and the set of predictors explains about $31 \%$ of the variability in the dependent variable. Beta coefficients of group collectivism and assertiveness are statistically significant.

Regression model with the dependent variable in novativeness and independent variable dimensions of GLOBE culture is significant at the $\mathrm{p}=0.00$ level. The multiple correlation coefficient $\mathrm{R}=0.391$ and the set of predictors explains about $15.3 \%$ of the variability in the dependent variable. Beta coefficients of group collectivism, assertiveness and gender equality are statistically significant.

Regression model with the dependent variable autonomy and independent variable dimensions of GLOBE culture is significant at the $\mathrm{p}=0.00$ level. The multiple correlation coefficient $\mathrm{R}=0.570$ and the set of predictors explains about $32.5 \%$ of the variability in the dependent variable. Beta coefficients of group collectivism and assertiveness are statistically significant.

Regression model with the dependent variable risk readiness and independent variable dimensions of GLOBE culture is significant at the $\mathrm{p}=0.00$ level. The multiple correlation coefficient $\mathrm{R}=0.597$ and the set of predictors explains about $35.6 \%$ of the variability in the dependent variable. Beta coefficients of uncertainty avoidance, group collectivism and assertiveness are statistically significant.

\section{Discussion}

Previous research investigated the relationship between GLOBE cultural dimensions and entrepreneurship (Castillo-Palacio et al. (2017), as well as the influence of Hofstede's cultural dimensions on entrepreneurship (Block \& Walter, 2017). Our previous research demonstrated the relationships between GLOBE dimensions, facets of job satisfaction and the leader-member exchange (Vukonjanski et al., 2012), as well as between GLOBE dimensions, communication satisfaction and emotional intelligence (Nikolić et al. 2014). The relationship between two of the GLOBE cultural dimensions (PO and $\mathrm{HO}$ ) and two of the EO dimensions (RiskT and Proact) was previously investigated in South Korea and Thailand (Yoo, 2015). How- ever, our study shows the influence between all nine GLOBE dimensions and six EO dimensions in the service sector in Serbia. The results from the statistical analysis are summarized in Figure 1.

The obtained results, in the case of the regression model with work ethic as criterion variable, indicate the negative influence of uncertainty avoidance and assertiveness, and positive influence of performance orientation and in group collectivism. Yoo (2015) showed the positive influence of performance orientation on Risk taking and Proactiveness. A high level of performance orientation implies readiness of the society to reward a high level of performance, which can be one of the driving factors for the high level of 


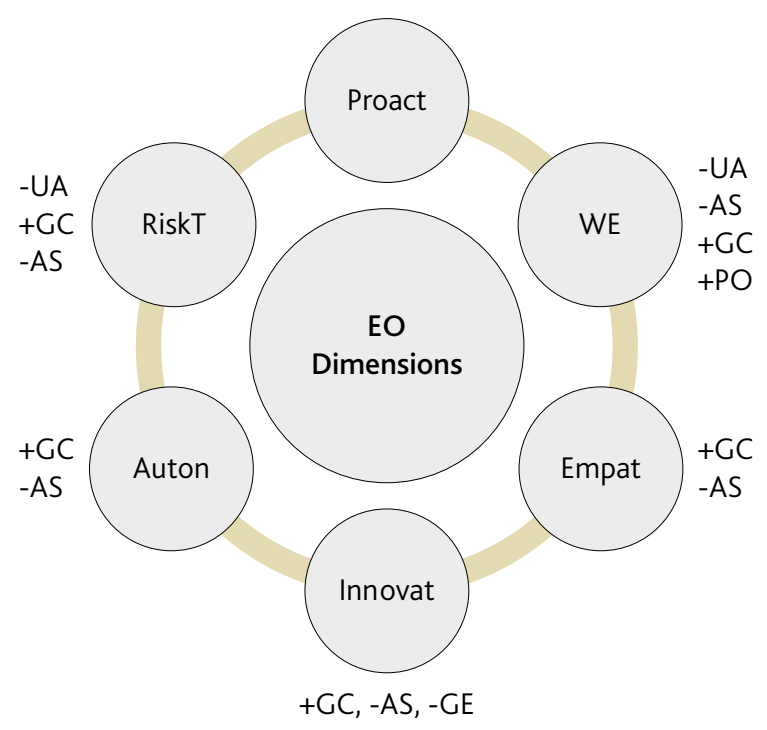

Figure 1. The identified statistically significant influences of dimensions of culture on the dimensions of entrepreneurial orientation (EO)

work ethic. In a society with a high degree of uncertainty avoidance, it is expected that everything is well planned, which can reduce the work ethic of the respondents in a highly individualized service sector (measured in this questionnaire with motivation for work, value, and willingness to meet challenges). Previous research by Engelen, Schmidt \& Buchsteiner (2015) found no empirical support for the interaction effect on EO of market turbulence and uncertainty avoidance.

According to the previous GLOBE-related study (Dickson et al., 200o), external influences on organizational culture are multiple and their influences may be complex. One of the specificities of the tourism and medical sectors is the high degree of interconnectivity of providers of partial services, which enable the formation of a complex service. For example, in the tourism sector, it is the connection of employees in the tourism and cultural sector, which is manifested by tourists' visits to cultural institutions - museums, galleries, archeological sites (Hadžić, 2005), and in the medical sector, for example, it can be a conciliatory decision making. It is clear therefore that the respondents' perception of a high level of group collectivism encourages the respondent to express a high level of work ethic orientation. The perception of a high level of assertiveness was followed in our sample by a low level of group collectivism. Such result is understandable, given that a high level of assertiveness in society indicates a high level of rudeness, unkindness and domination. This may discourage an employee from trying to establish a collaborative stakeholder network, so necessary with the provision of high quality service.

The statistical results in the model with the criterion variable empathy showed that there is a positive influence of group collectivism and the negative influence of assertiveness. Previously, Saeed et al. (2014) showed that assertiveness, market size and regulatory quality are no relevant moderators of the EO-performance relationship. High level of empathy reflects the respondent's willingness to develop strong personal relationships with the service user and to focus on meeting his / her requirements, which is an important condition for the service users' perception of the high level of services (Humphrey, 2013). The positive regression coefficient between independent variable group collectivism and dependent variable empathy means that as the level of perceptions of group collectivism increases the perception of entrepreneurial orientation-empathy is also increasing. This is understandable, because a high level of group collectivism also means a willingness to help group members. Entrepreneurs high on empathy will be more successful at motivating and leading their employees and helping their employees to cope with workplace stresses (Humphrey, 2013). The aforementioned characteristics of a society with a high degree of assertiveness "fits" very poorly with empathy, which results in a corresponding regression coefficient being significant and negative.

The regression model in which the criterion variable is innovativeness indicated the positive influence of group collectivism and negative influence of assertiveness and gender equality. High level of innovativeness means the respondents' willingness to engage in innovative activities with a desire to be respected and valued among their colleagues (one of the items was "I want to be known among my colleagues as an innovator"). The high level of group collectivism creates a good environment for a successful innovator (Goncalo \& Staw, 2006) in the tourism and medical sectors to be accepted in society and to be appreciated by both their colleagues and service users. On the other hand, a high level of assertiveness (which implies both aggression in the society and a desire for domination) is not a good environment for accepting and respecting very successful people, who may be deterred by the assertive members of the society. Such a situation can influence creative members of an assertive society to reduce their innovative aspirations (a significant negative regression coefficient).

The regression model with the criterion variable autonomy, showed positive influence of group collectivism and negative influence of assertiveness. A high level of autonomy orientation (according to the questionnaire used) means that the respondents have the expectation that their ideas will be accepted and given a chance for their realization. Hence, a high level of group collectivism (which includes the support of colleagues in the workplace but also members of the wid- 
er family) (House et al., 2004), allows a good environment for autonomous action. The negative influence of assertiveness on autonomy can be ascribed to the negative effect of increased aggressiveness in the society, similarly to the above discussed effect of assertiveness on innovativeness.

The regression model with risk readiness as the criterion variable showed negative influence of uncertainty avoidance and assertiveness, and positive influence of group collectivism. Kreiser et al. (2010) show that uncertainty avoidance and power distance have a significant negative influence on risk taking. Respondents who perceive a high degree of uncertainty avoidance in the society have a lower degree of risk orientation. One explanation may be that in a company with a high degree of uncertainty avoidance, there is less institutional support (for example, financial) for projects that are rated as risky in terms of performance (it is difficult to obtain favorable loans for small entrepreneurs without a high guarantee on the loans obtained). Thomas \& Mueller (2000), as well as Shane (1995) point to a negative correlation between uncertainty avoidance and entrepreneurial activity, considering that a society with a high degree of uncertainty avoidance is not prone to risk-taking activities and that members of such a society have low levels of readiness for changes, which is important for entrepreneurial activities. This can discourage potential entrepreneurs from embarking on an entrepreneurial venture, which can also reduce their willingness to take risks. On the other hand, the perception of a high level of group collectivism can encourage entrepreneurs to start an entrepreneurial venture as they can expect the support of the group (most often families), in the absence of institutional support.

According to our previous study (Nedeljkovic at al. 2018), a high score for the dimension of group collectivism (as it is) in Serbia was noted (mean 5.33), which can positively influence the development of entrepreneurial activities in Serbia.

\section{Conclusion}

This study demonstrates for the first time that GLOBE Culture dimensions are predictors of the dimensions of entrepreneurial orientation.

The following significant influences are revealed:

- Uncertainty avoidance, performance orientation, group collectivism and assertiveness are significant predictors of work ethic.

- Group collectivism and assertiveness are significant predictors of empathy.

- Group collectivism, assertiveness and gender equality are significant predictors of innovativeness.

- Group collectivism and assertiveness are significant predictors of autonomy.

- Uncertainty avoidance, group collectivism and assertiveness are significant predictors of willingness to take risks.

Based on the results obtained, we can conclude that group collectivism has a positive effect on all dimensions of entrepreneurial orientation except for proactiveness. Group collecivism implies support from the group, but also from the wider family, which can be a very significant support for starting entrepreneurial activities especially in the societies without clearly defined institutional support for entrepreneurship development. Research findings also indicate a high level of uncertainty avoidance, which is particularly negatively related to risk readiness. The recommendation to strategists and government agencies is to encourage employees through internal entrepreneurship, to encourage new business ideas and to introduce financial support for the development of new ideas, even though they bring a dose of risk in terms of their successful implementation. It is possible that this would reduce the high level of uncertainty avoidance in Serbian society, which is very important for a society's readiness for change. Dealing with change and responding appropriately to changes in the environment is very important to gain competitiveness in the global market. In addition to avoiding uncertainty, assertiveness was identified as a dimension of culture that adversely affects individual dimensions of entrepreneurial orientation. Although assertive behavior in some societies is considered useful in the business environment, we believe that the positive aspects of this dimension of culture are not well known in the Serbian culture. Hofstede's (2001) research on the dimensions of culture in the former Yugoslavia showed that the Serbian society is characterized by extremely strong collectivism and that much attention is paid to interpersonal relations in the work environment, even to the detriment of competitiveness. Therefore, in such society assertiveness may be perceived as harshness in relation to peers, bringing negative effects to the entrepreneurial orientation. We believe that through the education of students, especially in the study programs regarding entrepreneurship, it would be useful to point out the positive aspects of assertiveness, thus reducing the gap in relation to this cultural dimension in the Serbian society.

From the practical viewpoint the results of this study could be valuable for policy makers as well as 
for managers. The results obtained are important for defining a cultural framework that can significantly influence the development of entrepreneurial activities, which is of particular importance for transition societies such as Serbian society.
We suggest further evaluation of the influence of cultural dimensions on entrepreneurial orientation in other developing and developed countries, in different sectors of industry, to generate a wider view on the influence of personality dimensions of entrepreneurial orientation.

\section{Acknowledgments}

The research was supported by Ministry of Education, Science and Technological Development, Republic of Serbia (Grant No. OI17602o, Transformation of Serbian Geospace - the Past, Contemporary Problems and Possible Solutions).

\section{References}

Albert, M. N., \& Couture, M. M. (2013). The support to an entrepreneur: from autonomy to dependence. Sage Open, 3(2), DOI:10.1177/2158244013492779.

Avlonitis, G. J., \& Salavou, H. E. (2007). Entrepreneurial orientation of SMEs, product innovativeness, and performance. Journal of Business Research, 6o(5), 566-575.

Baluku, M.M., Kikooma, J.F., Bantu, E., Onderi, P., Otto, K. (2019) Impact of personal cultural orientations and cultural intelligence on subjective success in self-employment in multi-ethnic societies. Journal of Global Entrepreneurship Research, 9, 8

Bilgihan, A. and Nejad, M. (2015), "Innovation in hospitality and tourism industries", Journal of Hospitality and Tourism Technology, 6, 3 .

Block, J. H., \& Walter, G. S. (2017). Hofstede's cultural dimensions and modes of entry into entrepreneurship. In J. Bonnet, M. Dejardin, \& D. Garcia Perez De Lema (Eds.), Exploring the entrepreneurial society institutions, behaviors and outcomes (pp. 2234). Cheltenham, UK: Edward Elgar Publishing.

Bonder, B., Martin, L., \& Miracle, A. (2001). Achieving cultural competence: The challenge for clients and healthcare workers in a multicultural society. Generations, 25(1), 35-42.

Cambridge: Cambridge University Press.

Castillo-Palacio, M., Batista-Canino, R. M., \& Zuñiga-Collazos, A. (2017). The relationship between culture and entrepreneurship: from cultural dimensions of GLOBE project. Rev. Espacio 38, 12-26.

Carmichael, B. A., \& Morrison, A. (2011). Tourism entrepreneurship research. Tourism Planning \& Development, 8:2, 115-119, DOI: 10.1080/21568316.2011.573910.

Chang, J. (2011). Introduction: Entrepreneurship in tourism and hospitality: The role of SMEs. Asia Pacific Journal of Tourism Research, 16(5), 467-469.

Connell, J. (2006). Medical tourism: Sea, sun, sand and... surgery. Tourism management, 27(6), 1093-1100.
Covin, J. G., \& Slevin, D. P. (1986). The development and testing of an organizational-level entrepreneurship scale. Frontiers of entrepreneurship research, 1(3), 628-639.

Covin, J. G., \& Wales, W. J. (2012). The measurement of entrepreneurial orientation. Entrepreneurship theory and practice, 36(4), 677-702.

Dickson, M. W., Aditya, R. N., \& Chhokar, J. S. (2000). Definition and Interpretation in Cross-Cultural Organizational Culture Research: Some Pointers from the GLOBE Research Program. In N.M Ashkanasy, C.P.M Wilderom, \& M.F Peterson (Eds.), Handbook of organizational culture and climate (pp. 152). Thousand Oaks, CA: Sage Publications, Inc.

Engelen, A., Schmidt, S., \& Buchsteiner, M. (2015). The simultaneous influence of national culture and market turbulence on entrepreneurial orientation: A nine-country study. Journal of International Management, 21(1), 18-30.

Emrich, C. G., Denmark, F. L., \& Den Hartog, D. N. (2004). Cross-cultural differences in gender egalitarianism: Implications for societies, organizations, and leaders. Culture, leadership, and organizations: The GLOBE study of, 62, 343-394.

Fink, R. (2018). Health Tourism in the EU: Facts and Figures. Availabe at https://pro.regiondo.com/ health-tourism-eu/

Freytag, A., \& Thurik, R. (2007). Entrepreneurship and its determinants in a cross-country setting. Journal of evolutionary Economics, 17(2), 117-131.

Goncalo, J. A., \& Staw, B. M. (2006). Individualismcollectivism and group creativity. Organizational behavior and human decision processes, 100(1), 96-109.

Gredičak, T., \& Demonja, D. (2019). Potential Directions of Strategic Development of Medical Tourism: The Case of the Republic Of Croatia. Geographica Pannonica, doi: 10.5937/gp24-21485.

Hayton, J. C., George, G., \& Zahra, S. A. (2002). National culture and entrepreneurship: A review of 
behavioral research. Entrepreneurship theory and practice, 26(4), 33-52.

Hermansen-Kobulnicky, C. J., \& Moss, C. L. (2004). Pharmacy student entrepreneurial orientation: a measure to identify potential pharmacist entrepreneurs. American Journal of Pharmaceutical Education, 68(5), 113.

Hofstede, G. (2001). Culture's Consequences: comparing values, behaviors, institutions, and organizations across nations (2nd ed.). Thousand Oaks, CA: SAGE Publications.

Hojat, M., Gonnella, J. S., Mangione, S., Nasca, T. J., Veloski, J. J., Erdmann, J. B, \& Magee, M. (2002). Empathy in medical students as related to academic performance, clinical competence and gender. Medical education, 36(6), 522-527.

Hopkins, L., Labonté, R., Runnels, V., \& Packer, C. (2010). Medical tourism today: what is the state of existing knowledge?. Journal of public health poli$c y, 31(2), 185-198$.

House, R., Hanges, P., Javidan, M., Dorfman, P., \& Gupta, V. (2004). Culture, Leadership, and Organizations: The GLOBE study of 62 societies. London: SAGE Publications.

House, R., Javidan, M., Hanges, P., \& Dorfman, P. (2002). Understanding cultures and implicit leadership theories across the globe: an introduction to project GLOBE. Journal of world business, 37(1), 3-10.

Humphrey, R. H. (2013). The benefits of emotional intelligence and empathy to entrepreneurship. Entrepreneurship Research Journal, 3(3), 287-294.

Khandwalla, P.N. (1976/1977). Some top management styles, their context, and performance. Organization and Administrative Sciences, 7(4), 21-51.

Kreiser, P. M., Marino, L. D., Dickson, P., \& Weaver, K. M. (2010). Cultural influences on entrepreneurial orientation: The impact of national culture on risk taking and proactiveness in SMEs. Entrepreneurship theory and practice, 34(5), 959-984.

Lee, S. M., \& Peterson, S. J. (2000). Culture, entrepreneurial orientation, and global competitiveness. Journal of world business, 35(4), 401-416.

Lordkipanidze, M., Brezet, H., \& Backman, M. (2005). The entrepreneurship factor in sustainable tourism development. Journal of cleaner production, 13(8), 787-798.

Lumpkin, G. T., \& Dess, G. G. (1996). Clarifying the entrepreneurial orientation construct and linking it to performance. Academy of management Review, 21(1), 135-172.

Lumpkin, G. T., \& Dess, G. G. (2001). Linking two dimensions of entrepreneurial orientation to firm performance: The moderating role of environment and industry life cycle. Journal of business venturing, 16(5), 429-451.

Mebrahtu, T., Crossley, M., \& Johnson, D. (Eds.). (2000). Globalisation, educational transformation and societies in transition. Symposium Books Ltd.

Miller, D., \& Friesen, P. H. (1982). Innovation in conservative and entrepreneurial firms: Two models of strategic momentum. Strategic management journal, 3(1), 1-25.

Money, R. B., \& Crotts, J. C. (2003). The effect of uncertainty avoidance on information search, planning, and purchases of international travel vacations. Tourism Management, 24(2), 191-202.

Montanye, J. A. (2006). Entrepreneurship. The Independent Review, 10 (4), 547-569.

Morris, M. H., Davis, D. L., \& Allen, J. W. (1994). Fostering corporate entrepreneurship: Cross-cultural comparisons of the importance of individualism versus collectivism. Journal of International Business Studies, 25(1), 65-89.

Morris, M. H., Davis, D. L., \& Allen, J. W. (1994). Fostering corporate entrepreneurship: Cross-cultural comparisons of the importance of individualism versus collectivism. Journal of International Business Studies, 25(1), 65-89.

Munck, R. (2002). Democracy and development: deconstruction and debates. In Sklair, L. (Ed.) Capitalism and development (pp.21-39). London: Routledge.

Naldi, L., Nordqvist, M., Sjöberg, K., \& Wiklund, J. (2007). Entrepreneurial orientation, risk taking, and performance in family firms. Family business review, 20(1), 33-47.

Nedeljković, S., Koković, D. i Nedeljković, M. (2010). Uticaj nacionalne kulture na ponašanje potrošača i zaposlenih u turističkom sektoru-primena teorije Hofstede-a, Zbornik Matice srpske za društvene nauke, 130: 43-61.

Nedeljković, M., Vukonjanski, J., Nikolić, M., Hadzic, O., \& Šljukić, M. (2018). A comparative analysis of Serbian national culture and national cultures of some European countries by GLOBE project approach. J. Geogr. Inst. Cvijic. 68(3) (363-382)

Nikolić. M., Vukonjanski, J., Nedeljković, M., Hadžić, O., \& Terek, E. (2014). The relationship between communication satisfaction, emotional intelligence and the GLOBE organizational culture dimensions of middle managers in Serbian organizations. Journal for East European Management Studies, 19(4), 387-412.

Özsomer, A., Calantone, R. J., \& Di Bonetto, A. (1997). What makes firms more innovative? A look at organizational and environmental factors. Journal of Business \& Industrial Marketing, 12(6), 400-416 
Palich, L. E., \& Bagby, D. R. (1995). Using cognitive theory to explain entrepreneurial risk-taking: Challenging conventional wisdom. Journal of business venturing, 10(6), 425-438.

Pavluković, V., Armenski, T., \& Alcántara-Pilar, J. M. (2017). Social impacts of music festivals: Does culture impact locals' attitude toward events in Serbia and Hungary? Tourism Management, 63, 42-53.

Rostow, W.W. (1960). The Stages of Economic Growth: A Non-Communist Manifesto.

Saeed, S., Yousafzai, S. Y., \& Engelen, A. (2014). On cultural and macroeconomic contingencies of the entrepreneurial orientation-performance relationship. Entrepreneurship Theory and Practice, 38(2), 255-290

Shane, S. (1993). Cultural influences on national rates of innovation. Journal of business venturing, 8(1), 59-73.

Shane, S. (1995). Uncertainty avoidance and the preference for innovation championing roles. Journal of international business studies, 26(1), 47-68.

Spence, J. T. (1985). Achievement American style: The rewards and costs of individualism. American Psychologist, 40(12), 1285.
Thomas, A. S., \& Mueller, S. L. (2000). A case for comparative entrepreneurship: Assessing the relevance of culture. Journal of international business studies, 31(2), 287-301.

Tsang, N. K. F., \& Ap, J. (2007). Tourists' perceptions of relational quality service attributes: A cross-cultural study. Journal of Travel Research, 45(3), 355-363.

Vukonjanski, J., Nikolić, M., Hadžić, O., Terek, E., \& Nedeljković, M. (2012). Relationship between GLOBE organizational culture dimensions, job satisfaction and leader-member exchange in Serbian organizations. Journal for East European Management Studies, 17(3), 333-368.

Yoo, K.-S. (2015) A Comparative Study of Cultural Dimension as an Influencing Factor to

Entrepreneurial Orientation, International Journal of Business and Social Science 6(2), 192-206

Zion Market Research (2018). Medical Tourism Market by Treatment Type (Cancer Treatment, Orthopedic Treatment, Fertility Treatment, Cardiovascular Treatment, Neurological Treatment, and Others): Global Industry Perspective, Comprehensive Analysis, and Forecast, 2017 - 2024. 